\title{
ECOTOURISM CERTIFICATION PROGRAMS: STANDARDS AND BENEFITS
}

\author{
Mariia HOLUB', \\ Simon Kuznets Kharkiv National University of Economics, Ukraine
}

\begin{abstract}
The problem of researching the ecotourism certification processes in the world is very up-to-date nowadays. The relevance of the research is stipulated by current state of environ-mental pollutants, the development of sustainable politics implementation and the fact that now people aware of real danger of environmental catastrophe that threatens the survival of civilization. That's why the purpose of the article is conducting a complex analysis of foreign ecotourism certi-fication programs. Moreover, it is necessary to study the evolution of ecotourism development to understand the key issues of this problem. The object of this article is the analysis of ecotourism certification worldwide. The subject of the article is the detection of theoretical, methodological and practical aspects of implementation of effective ecotourism certification programs in Ukraine. To clarify all aspects of studying this issue it is necessary to use such theoretical and methodological basis as: modern theories of the genesis and evolution of ecological tourism, logical and analogy analysis, historical method, hypothetical method, classification and graphical method. Using such methods it was found that the development of ecotourism formation has taking three evolutionary steps, which affected the creation of its definition. This fact reveals the classification of different types of sustainable tourism and provides an impetus of ecotourism certification studies. Moreover, it was identified that there is a logical regularity in ecotourism certification programs all over the world. As the result, it was found that practically all the ecotourism certification processes are functioning successfully nowadays. By the way, it can be observed the rapid increase in the amount of ecocertified companies. Moreover, the programs which were analyzed in this article were divided into several steps (depends on the ecotourism certification program) following which a company can successfully passed the assessment process. Unfortunately, there is no such certification processes in Ukraine. That's why the issue of developing ecotourism services certification in Ukraine is urgent nowadays. Practical implications. However, analysis of the experience of foreign countries can be the basis for the development of ecotourism services certification in Ukraine. Value/originality. Modeling processes of ecotourism certification of different programs will help to emphasize the details of assessing ecotourism potential in Ukraine.
\end{abstract}

Key words: ecological tourism, sustainable development, ecotourism certification, mass and alternative tourism, sustainable tourism.

\section{JEL Classification: L83, Q56, Q57}

\section{Introduction}

The current state of environmental pollutants in the all countries is a testament to the need to resolve the issues of efficient use of natural resources. Another important issue for Ukraine is the international integration to the world economy. On the one hand it is a sustainable development of industrial areas. On the other hand, there should be given the need for simultaneous combination of economic and environmental interests of Ukraine. That's why the problem of developing ecological tourism is very up-to-date not only for Ukraine, but also for each citizen of our Earth. Moreover, the organization of monitoring the tourism entrepreneurs in ecological sphere is crucial nowadays.

The issue of ecotourism certification is aim of many scientific discussions all over the world. Unfortunately, this problem isn't investigated profoundly yet in Ukraine. However, various aspects of the development of the implementation of ecocertification processes were studied by such scien-tists as: M. Honey and A. Rome, X. Font and J. Bendell, A. Bien, M. Wood and others.

That's why the purpose of the article is conducting a complex analysis of foreign ecotourism certification programs. Moreover, it is necessary to study the evolution of ecotourism development to understand the key issues of this problem. The object of my research is the analysis of ecotourism certification worldwide. The subject of my research work is the detection of theoretical, methodological and practical aspects of implementation of effective ecotourism certification pro-grams in Ukraine. To clarify all aspects of studying issue it is necessary to use such

\footnotetext{
Corresponding author

${ }^{1}$ Department of International Economic Relations, Simon Kuznets Kharkiv National University of Economics.

E-mail: mary.may@list.ru
} 
theoretical and methodological basis as: modern theories of the genesis and evolution of ecological tourism, logical and analogy analysis, historical method, hypothetical method, classification and graphical method. To achieve the purpose it is necessary to solve the following tasks: to examine the existing ex-perience of the theoretical foundations and methods of ecotourism research area; to select the most successful programs of ecotourism certification; to conduct the complex analysis of these programs.

\section{The ecotourism evolution}

Ecotourism is a growing niche market within the larger travel industry, with the potential of being an important sustainable development tool. With billions of dollars in annual sales, ecotourism is a real industry that seeks to take advantage of market trends. At the same time, it frequently operates quite differently than other segments of the tourism industry, because ecotourism is de-fined by its sustainable development results: conserving natural areas, educating visitors about sus-tainability, and benefiting local people (Wood, 2002).

However, it was found that such situation wasn't observed all the time. Throughout the de-velopment of tourism in different times people had different purpose during traveling. Today, peo-ple aware of real danger of environmental catastrophe that threatens the survival of civilization. This caused early development of alternative kinds of tourism, trying to minimize the negative impact. One of these ways can be a new evolutionary step, where ecotourism is seen as a setoff to mass tourism. This process is depicts schematically on Fig. 1.

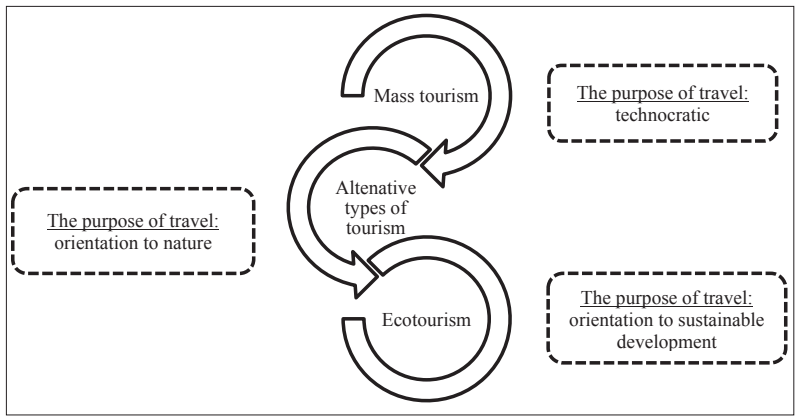

Fig. 1. The process of ecotourism evolution

This indicates that at the present stage of development of tourism tourists' outlooks have changed dramatically. The sustainable development of all sectors of the economy has become more important. Note that now tourists have started to act more responsible during visiting tourism desti-nations. Also, ecotourism is an auxiliary element in the development of sustainable economic de-velopment.

Although ecotourism may share some of its aspects with other forms of tourism, it should be viewed as distinct from the other categories of tourism (Tab. 1). When properly understood, eco-tourism goes further by striving to respect and benefit protected areas as well as the people living around or on the land (Honey, 2008)
Table 1 (IGAD, 2011)

Categories of tourism

\begin{tabular}{|l|l|}
\hline $\begin{array}{l}\text { Nature } \\
\text { tourism }\end{array}$ & $\begin{array}{l}\text { Travelling to unspoiled places to experience and } \\
\text { enjoy nature. It involves moderate and safe forms } \\
\text { of exercise such as hiking, biking, sailing and } \\
\text { camping. }\end{array}$ \\
\hline $\begin{array}{l}\text { Wildlife } \\
\text { tourism }\end{array}$ & $\begin{array}{l}\text { Travelling where the main attraction is to watch } \\
\text { animals, birds and fish in their native habitats. }\end{array}$ \\
\hline $\begin{array}{l}\text { Adventure } \\
\text { tourism }\end{array}$ & $\begin{array}{l}\text { Nature tourism which requires physical skill and } \\
\text { endurance (rope climbing, deep-sea div-ing, } \\
\text { bicycling, water rafting or kayaking) and involves } \\
\text { a degree of risk taking, often in little-charted } \\
\text { terrain }\end{array}$ \\
\hline $\begin{array}{l}\text { Alternative } \\
\text { tourism }\end{array}$ & $\begin{array}{l}\text { Tourism with a small or specialist market, or } \\
\text { product that is distinct from mainstream or mass } \\
\text { tourism. }\end{array}$ \\
\hline $\begin{array}{l}\text { Green } \\
\text { tourism }\end{array}$ & $\begin{array}{l}\text { An early term essentially synonymous with } \\
\text { ecotourism, but never very well defined. }\end{array}$ \\
\hline $\begin{array}{l}\text { Cultural } \\
\text { tourism }\end{array}$ & $\begin{array}{l}\text { Tourism that focuses on exposing or introducing } \\
\text { tourists to different local cultures. }\end{array}$ \\
\hline $\begin{array}{l}\text { Outdoor } \\
\text { tourism }\end{array}$ & $\begin{array}{l}\text { All forms of tourism that take place outdoors } \\
\text { including high-impact and consumptive tourism } \\
\text { such as motorized vehicles, hunting etc }\end{array}$ \\
\hline $\begin{array}{l}\text { Sustainable } \\
\text { tourism }\end{array}$ & $\begin{array}{l}\text { Sustainable tourism is "envisaged as leading to } \\
\text { management of all resources in such a way that } \\
\text { economic, social and aesthetic needs can be } \\
\text { fulfilled while maintaining cultural integrity, } \\
\text { essential ecological processes, biological diversity } \\
\text { and life support systems" }\end{array}$ \\
\hline
\end{tabular}

A clear distinction should be made between the concepts of ecotourism and sustainable tour-ism (Fig. 2).

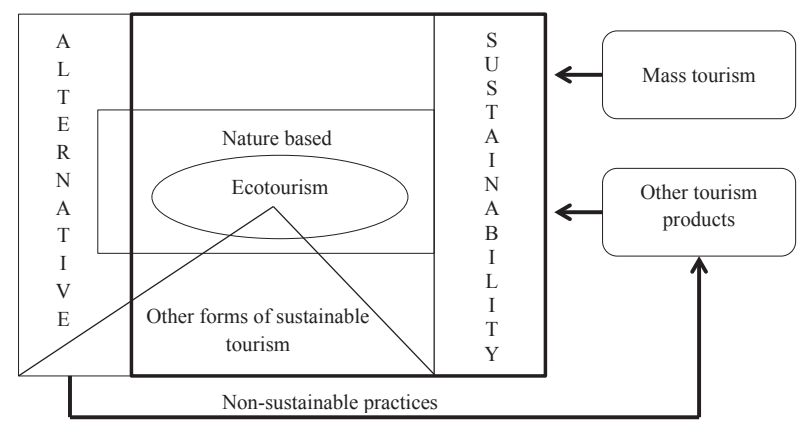

Fig. 2. Position of ecotourism within the tourism spectrum (IGAD, 2011)

The term ecotourism refers to a sub-sector within the tourism industry that focuses on mini-mizing environmental and cultural consequences, contributes to conservation, community projects and environmental education. On the other hand sustainability principles apply to all types of tour-ism activities, operations, establishments and projects, including conventional and alternative forms (UNWTO, 2013). Because ecotourism was originally just an idea, not a discipline, many business and governments promoted it without an understanding of its most basic principles. The interna-tional Ecotourism 
Society has tracked the results of stakeholder meetings since 1991 to develop the set of principles, which are being embraced by a growing constituency of non-governmental organi-zations, private sector business, governments, academia and local communities (Wood, 2002). These principles are shown on Fig. 3.

The benefits of ecotourism flowing to local businesses are also dramatically higher than those from mass tourism. Standard all-inclusive package tours typically deliver just $20 \%$ of revenue to local companies, while airlines, hotels and large tour companies capture the rest. In contrast, ecotourism operations that are based and hire locally can return as much as $95 \%$ of in-country ex-penses to the local economy (UNEP, 2013). There are quite favorable conditions and resources for the development of ecotourism in Ukraine. Unfortunately, underdeveloped tourism infrastructure has led to the fact that ecotourism stays behind global trends. As many scientists estimate, there is a great potential for the development of ecotourism in protected areas. However, it is important to remember, that ecotourism is not only a holiday reserved territories but also preserve "wilderness" in the mountainous and woodland territories of Ukraine. Ukraine has great recreational potential, and with the right approach ecotourism can become a great part in the process of the replenishment of the state budget. That's why it is very important to conduct the certification of ecotourism ob-serving the experience of foreign countries.

\section{Foreign experience \\ of ecotourism certification}

More than 61 countries had at least one, and some countries more, standards of voluntary certification in the field of tourism in 2012 (UNWTO, 2013). There we can find Ukraine. However, it should be noted that although our country has adopted state-level standardization and certification of tourism services, the ecotourism certification process wasn't considered in any of these documents. This fact indicates the need of implementation such certificates.

Certification is a way of ensuring that an activity or a product meets certain standards. With-in the tourist industry, different organizations have developed certification programs measuring dif-ferent aspects of tourism: quality, for the entire tourism industry; sustainability, also for all sectors; ecotourism, for sustainable tourism that takes place in natural, protected, or fragile ecosystems, that may include indigenous communities, and that conforms to the definition above (Bien, 2006).

American scientists M. Honey and A. Rome underline that certification is a voluntary pro-cedure that assesses, audits and gives written assurance that a facility, product, process or service meets specific standards. It awards a marketable logo to those that meet or exceed baseline stand-ards (Honey, Rome, 2000). However, due to the fact, that there is no any certificate like this in Ukraine, it is important to analyze foreign experience in ecotourism certification. This research will help to find out the basic rules for future studies in Ukraine.

Nowadays it is used to incline that such certification should be controlled and supported by the government. Spanish scientists X. Font and J. Bendell mapped out how governments take ac-tions to enable the operation of certification programs. 20 of the 59 schemes are led by government agencies, and a further 18 have government involvement either through direct financial support, marketing support, verification procedures, or surveillance of procedures being followed by the certification body. Government agencies involved generally include both environmental ministries (or equivalent) and tourism boards; in fewer cases standards institutes have an involvement. Govern-ment financial support is crucial to half the programs, and grants or loans are available

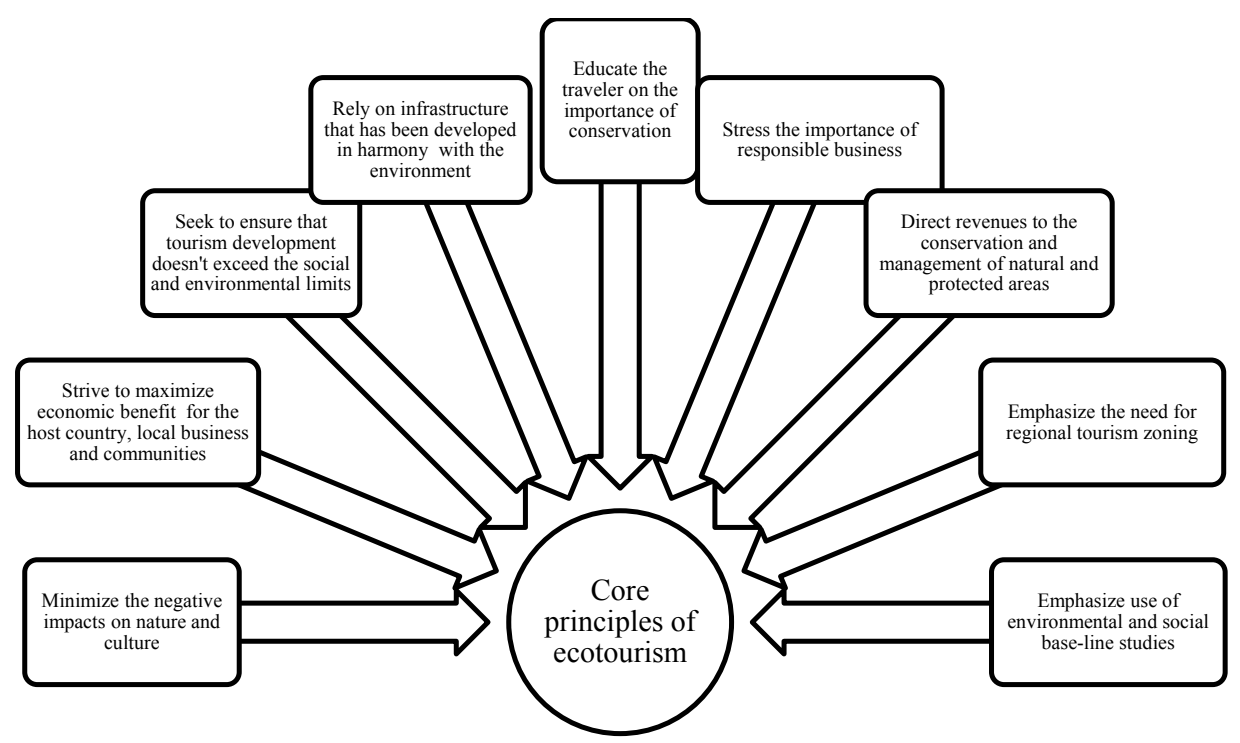

Fig. 3. Principles of ecotourism 
through a variety of support measures for consultants and assessment processes (Font, Bendell, 2002).

Center of Ecotourism and Sustainable Development recon that a major problem for true eco-tourism businesses is a practice called greenwashing. This term refers to a business that presents itself as "sustainable", "ecological", "green”, "responsible”, “ecotourist”, etc., when it doesn't com-ply with generally accepted standards, or worse, it is in contradiction with them. For those who are really trying to do their best to comply with all ecotourism standards, the businesses that falsely use the term 'ecotourism' compete unfairly and damage the credibility of the whole

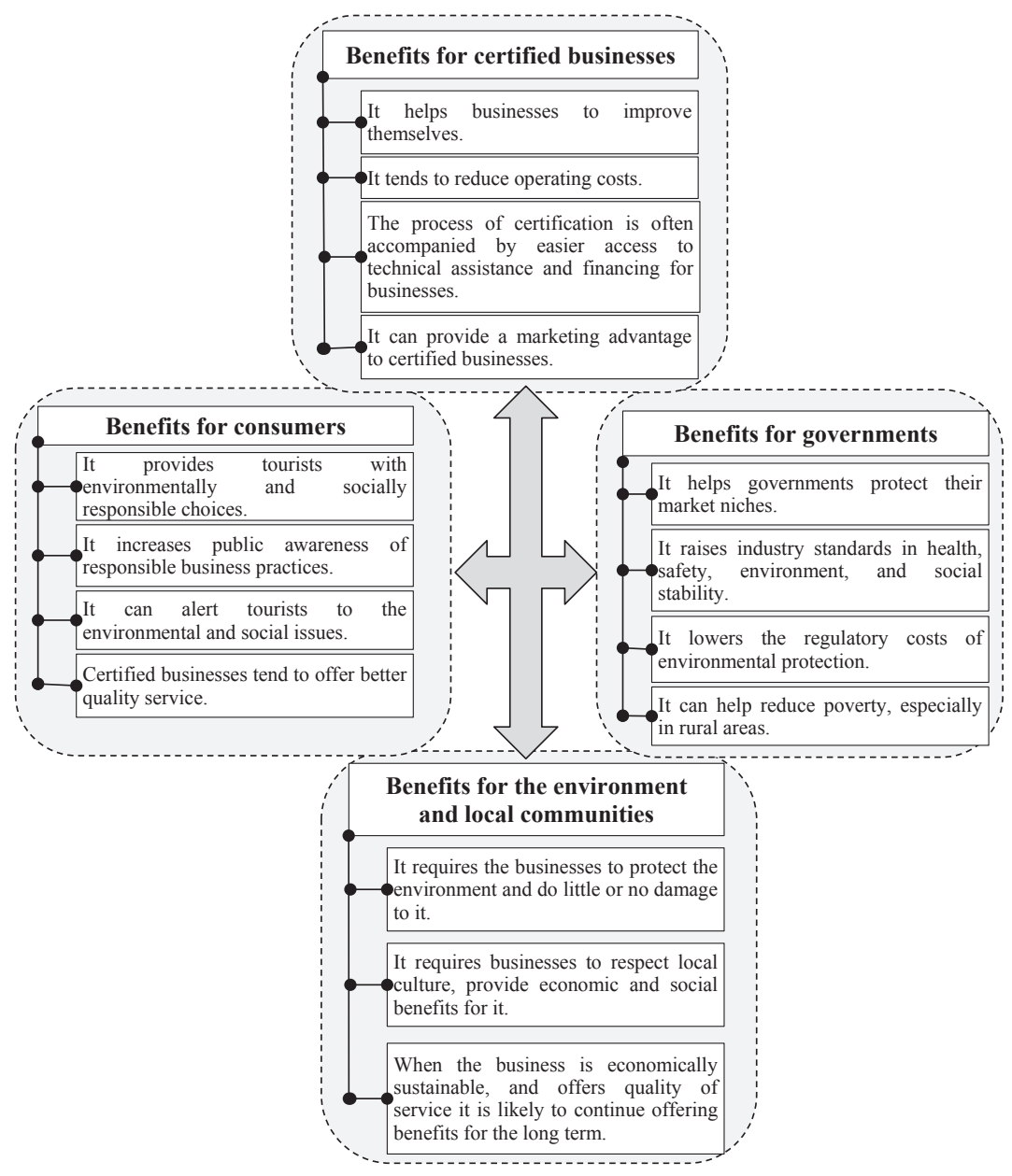

Fig. 4. Advantages of ecotourism certification implementation (Bien, 2006)

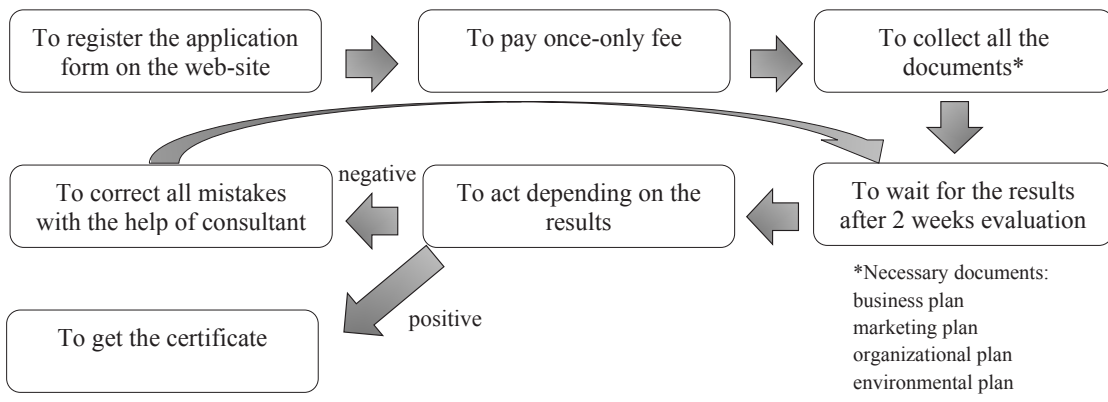

Fig. 5. The process of ecotourism certification in Australia (Ecotourism Australia, 2015) industry. One way of determining which businesses are truly practicing ecotourism is certification (Bien, 2006).

Certification is not an end in itself. It is one of a number of tools for motivating businesses and others to improve their environmental, social, and economic performance, while rewarding them for doing so. These rewards are sometimes tangible and sometimes not. There are a number of other reasons why certification is important (Fig. 4).

To understand clear the modern trends in ecotourism certification it is needed to study the worldwide known successful examples more accurate. For example, the government in Costa Rica initiates The Certification of Sustainable Tourism (CST) for companies that are following green politics (CST, 2013a; CST, 2013b). This certification is free and voluntary. CST includes a five-steps scale to assess the achievement of sustainable tourism (Tab. 2). Now more than 61 tour oper-ates have this certificate in Costa Rica (CST, 2013a; CST, 2013c)

Table 2 (Honey, Bien, 2005)

The level of sustainability

\begin{tabular}{|c|c|}
\hline Level & $\begin{array}{c}\text { Minimum percentage } \\
\text { of compliance }\end{array}$ \\
\hline 0 & $<20 \%$ \\
\hline 1 & $20 \%-39 \%$ \\
\hline 2 & $40 \%-59 \%$ \\
\hline 3 & $60 \%-79 \%$ \\
\hline 4 & $80 \%-94 \%$ \\
\hline 5 & $>94 \%$ \\
\hline
\end{tabular}

Tour operates have to answer 108 questions about sustainability in their organization. After that the special department evaluate the results and asses all the aspects in company. The process ends with the assignment of the appropriate level (CST, 2013d).

In addition, in Australia for example, there is the ECO Certification program. The ECO Cer-tification Program is a world first and it has been developed to address the need to identify genuine nature and ecotourism operators. ECO Certification is product-specific- this means that it is need-ed to answer the criteria as it applies specifically to each of products. The ECO Certification Pro-gram is divided into three levels. There are more than 450 certified entrepreneurs (Ecotourism Australia, 2015). To obtain this certificate it is needed to achieve steps, which are depicts in Fig. 5. 
This certification isn't free. The payment depends on company's turnover (Tab. 3).

Table 3 (Ecotourism Australia, 2015) Payments for ecotourism certification in Australia

\begin{tabular}{|c|c|c|}
\hline Company's turnover & $\begin{array}{c}\text { Once-only } \\
\text { aplication fee }\end{array}$ & $\begin{array}{c}\text { Ongoing } \\
\text { annual fee }\end{array}$ \\
\hline$<\$ 250000$ & $\$ 395$ & $\$ 510$ \\
\hline$\$ 250001-\$ 1000000$ & $\$ 455$ & $\$ 730$ \\
\hline$\$ 1000001-\$ 5000000$ & $\$ 575$ & $\$ 1025$ \\
\hline$\$ 5000001-\$ 10000000$ & $\$ 695$ & $\$ 1225$ \\
\hline$>\$ 10000001$ & $\$ 925$ & $\$ 1360$ \\
\hline
\end{tabular}

After the company passed the inspection of all documents and paid the first payment, the organization sends certificate and marketing materials to achieve the results. Each year, companies have to pay the fee and send the completed annual declaration, where all the operational activites are observed. The monitoring the level of rules adequence is carried out every three years. Moreover, only after tourism company pay aplication fee, it will be provided with all rules needed to follow and the list of documents needed to be done, to achieve a certificate. Unfortunately, this example can't b used in Ukraine, because of tha lack of money in such organisation. Besides, people want to be confident in certification organisation. Therefore, the ecocertification process should be free and monitored by the government.

In Romania there is the Ecotourism Certification System (AER, 2015) It is a mechanism for putting into practice the basic principles of ecotourism, in order to ensure nature conservation and sustainable development of local communities through tourism. It is based on the Nature and Eco-tourism Accreditation Program promoted by the Australian Ecotourism Association (NEAP is the first accreditation system in ecotourism) and on Nature's Best developed by the Swedish Ecotour-ism Association (the first accreditation system in ecotourism in the northern hemisphere). The Eco-tourism Certification System addresses two different categories of applicants:

- ecotourism programs / tours provided by tour-operators (i.e. eco-tours of maximum 15 par-ticipants),

- small-scale accommodation structures in rural and natural areas (eco-lodges and guesthouses of maximum 25 rooms).

The certification system operates with a set of criteria established by the Association of Eco-tourism in Romania, which must be fulfilled by the products of the tour operator which is subject to the certification procedure. The criteria fall into two categories:

Basic criteria. These represent the basic norms that must be fulfilled by the product undergo-ing certification in order to obtain a temporary classification from the point of view of ecotourism.

Complementary criteria. These are the norms that establish the classification of a product in terms of ecotourism. Besides fulfilling the basic criteria, fulfilling $50 \%$ of the complementary criteria leads to certification of the product as complying with the principles of ecotourism.

$$
\begin{aligned}
& \text { Preliminary stage } \\
& \text { - to fill in a self-evaluation form for each of the products } \\
& \text { - to fill in an application form for certification } \\
& \text { First stage } \\
& \text { - to send all documents to the Certification Department within AER } \\
& \text { Second stage } \\
& \text { Third stage }
\end{aligned}
$$

Fig. 6. The ecotourism certification process in Romania 
Certification procedure takes 5 steps, which are depicted in Fig. 6.

To understand the results of the certification it is necessary to explain which of them. If an organization receive the decision "awarding", it means that the company will get the eco-certified logo over a period of 3 years if the products of the applicants fulfil all the applicable basic criteria plus a minimum $50 \%$ of the applicable complementary criteria.

In case of "temporary awarding" the company will get the eco-certified logo over a period of maximum one year and a half if the products of the applicants fulfil all the applicable basic criteria but do not fulfil minimum $50 \%$ of the applicable complementary criteria. The ecocertified logo is awarded temporarily on condition that this requirement is fulfilled within maximum a year.

If the company gets "not awarding" decision, it means that company's products fail to meet the requirements established in the evaluation criteria.

Withdrawal (over a period of up to 6 months) of the eco-certified logo for products that no longer fulfil initial awarding conditions, but that can be addressed within a time limit set by the Committee. For this to happen, the applicant will sign a statement regarding the measures taken in order to address the situation.

Final withdrawal of the eco-certified logo from the products that no longer fulfil the initial awarding conditions and that:

- can no longer be addressed; or

- have not been addressed within the time limit; or where - the operator has not signed the statement regarding the measures taken.

If the company wants to succeed it has to follow each step. This certification isn't free. The evaluation fee has been established in Euro and represents the equivalent in lei on the date of pay-ment. It consists of:

- travel costs of evaluators - 25 Euro/trip;

- accommodation costs - 25 Euro/night;

- evaluators' fees - 50 Euro/evaluation day;

- other costs (administrative costs) - 30 Euro/evaluated product.

For Ukraine, this mechanism can't be fully used because of the financial situation most of the companies. The same problem we observed in case of Australian ecotourism certification. The advantage of this certification is that companies are able to see in advance all the criteria for a full understanding if they can comply with the criteria. However, if a subjective assessment does not meet the objective one, the company can only submit in six months the next application certification. The company does everything independently, in contrast to the Australian certification system, where there is a special consultant who will help to get the certificate if your first try failed.

The Rainforest Alliance works with hotels, inbound and outbound tour operators and other tourism businesses to help them improve their environmental, social and economic practices. Our standard for tourism operations has been recognized by the Global Sustainable Tourism Council (GSTC). Through training and technical assistance, we teach them how to operate sustainably and assess their progress toward this goal. They create a Verification Standard 2.0 (Rainforest Alliance Verified, 2012). The Verification Standard 2.0 makes explicit the outcomes to be achieved as a result of the implementation of sustainable management at business level and the impacts on destinations. This allows designing assessment systems for these impacts, both for the business and the destination. The Verification Standard 2.0 is organized in three fields: business, cultural and environmental (Tab. 4).

Table 4

The structure of the Verification Standard 2.0

\begin{tabular}{|c|c|}
\hline Field & Principles \\
\hline \multirow{8}{*}{ The Business Field } & Sustainable management planning \\
\hline & Safety Management \\
\hline & Suppliers Management \\
\hline & Quality management \\
\hline & $\begin{array}{c}\text { Communication and Marketing } \\
\text { Management }\end{array}$ \\
\hline & Human Resources Management \\
\hline & Education for Sustainability \\
\hline & Health in Food and beverages services \\
\hline \multirow{4}{*}{$\begin{array}{l}\text { The Socio-cultural } \\
\text { Field }\end{array}$} & Contribution to local development \\
\hline & Respect to Local Cultures and People \\
\hline & Legality and Ethics of Labor Practices \\
\hline & $\begin{array}{l}\text { Rescue and Protection of Historical - } \\
\text { Cultural Heritage }\end{array}$ \\
\hline \multirow{7}{*}{$\begin{array}{c}\text { The Environmental } \\
\text { Field }\end{array}$} & Climate Change \\
\hline & Protection of Natural Areas \\
\hline & Rational Use of Water \\
\hline & Pollution \\
\hline & Rational Use of Energy \\
\hline & Integrated Solid Waste Management \\
\hline & Biodiversity Protection \\
\hline
\end{tabular}

All the principles are made operational through criteria and indicators that measure compliance. The indicators and assessment requirements may vary according to the business sector addressed by the verification tool (accommodation, tour operators, restaurants or community enterprises). Mandatory criteria for these sectors were defined.

So, each of the certificates has its own peculiarities. It is very important to understand details of the ecotourism certification process in case if company wants to obtain this certificate. It means that an activity or a product meets certain standards in quality and sustainability

\section{Conclusion}

To sum up, ecotourism is a fast growing sphere of tourism, with the potential of being an important sustainable development tool. This type of tourism has its principles which distinguish it from others. Moreover, it operates differently than other types of the tourism industry, because eco-tourism is defined by its sustainable 
development results: conserving natural areas, educating visitors about sustainability, and benefiting local people.

Center of Ecotourism and Sustainable Development recon that a major problem for true eco-tourism businesses is a practice called greenwashing. To solve this problem it was found the eco-tourism services certification which was characterized in this article. It should be noted that all the aforementioned ecocertification processes are functioning successfully nowadays. By the way, from year to year more and more companies have been changing their operational politics in the sphere of sustainable development. As the result for this, we can observe the rapid increase in the amount of ecocertified companies.

Unfortunately, there is no such certification processes in Ukraine. That's why the issue of developing ecotourism services certification in Ukraine is urgent nowadays. Moreover, in case of relying on foreign experience we must take into account the fact that the effect of implementation can be quite different in Ukraine. However, analysis of the experience of foreign countries can be a significant impetus for the development of ecotourism services certification in Ukraine.

\section{References}

AER (2015). Association of Ecotourism in Romania. Retrieved from http://www.eco-romania.ro/

Bien, A. (2006). A Simple User's Guide to Certification for Sustainable Tourism and Ecotourism, 3-d Edition Center of Ecotourism and Sustainable Development, $30 \mathrm{p}$.

CST (2013a). Sustainable Tourism CST: Certification for sustainable tourism in Costa Rica, Certi-fication for Sustainable Tourism's website. Retrieved from http://sustainabletourism.co.cr/

CST (2013b). When and why it appears? Certification for Sustainable Tourism's website. Retrieved from http://sustainabletourism.co.cr/

CST (2013c). Agencias tour operados, Certification for Sustainable Tourism's website. Retrieved from http://sustainabletourism.co.cr/

CST (2013d). What is CST all about?, Certification for Sustainable Tourism's website. Retrieved from http://sustainabletourism.co.cr/

Ecotourism Australia (2015). ROC Certification. Retrieved from http://www.ecotourism.org.au/

Font, X. and Bendell, J. (2002). Standards for sustainable tourism for the purpose of multilateral trade negotiations. World Tourism Organization, Madrid

Honey, M. \& Bien, A. (2005). Analyzing Costa Rica as a model for the implementation of market-ing certification in five target countries - A publication of Center on Ecotourism and Sustainable Development The International Ecotourism Society (TIES), 63 p.

Honey, M. \& Rome, A. (2000). Protecting Paradise: Certification Programs for Sustainable Tourism and Ecotourism. Washington, D.C.: Institute for Policy Studies, October 2001. Retrieved from http//www.conservationfinance.ort/ Documents/CF_related_papers/StandardsforParadose.pdf.

Honey, M. (2008). Ecotourism and Sustainable Development: Who Owns Paradise? (Second ed.). - Washington DC: Island Press, 568 p.

IGAD (2011). Ecotourism in the Intergovernmental Authority on Development - United Nations Economic Commission for Africa, $58 \mathrm{p}$.

Rainforest Alliance Verified (2012). Verification Standard for Tourism Services. Version 2.0 / Blanco Sosa, Saúl Antonio, González Oviedo, Marianela, Rioja Malasenkov, Silvia, 30 p.

UNEP(2013). Branching out for a green economy. United Nations Environment Programme, For-ests. Retrieved from http://www.unep.org/

UNWTO (2013). World Tourism Organization Retrieved from http://www.unwto.org

Wood, M. (2002). Ecotourism. Principles, practice and policies for sustainability - UNEP \& TIES. United Nation Publication, $32 \mathrm{p}$.

\section{Мария ГОЛУБ}

\section{ПРОГРАММЫ \\ СЕРТИФИКАЦИИ ЭКОЛОГИЧЕСКОГО \\ ТУРИЗМА: СТАНДАРТЫ \\ n ПРЕИМУЩЕСТВА}

Аннотация. В настоящее время во всем мире проблема исследования процессов сертификации экотуризма является очень важной. Стоит заметить, что актуальность исследования обусловлена текущим состоянием окружающей среды, темпами перехода компаний на устойчивое развитие, а также тот факт, что сейчас люди более осведомлены о реальной опасности экологической катастрофы, которая грозит вымиранию цивилизации. Именно поэтому, целью данной статьи является комплексный анализ зарубежных программ сертификации экотуристских услуг. Кроме того, необходимо изучить эволюцию развития экологического туризма, чтобы расставить ключевые моменты этой проблемы. Объектом изучения этой статьи является анализ сертификации экотуризма во всем мире. В свою очередь, предметом исследования этой статьи является выяв- 
ление теоретических, методологических и практических аспектов реализации в Украине мировых программ сертификации экологического туризма, которые активно и эффективно функционируют. Для уточнения всех ключевых моментов изучения данной проблемы необходимо использовать следующую теоретическую и методологическую основу: современные теории генезиса и эволюции экологического туризма, логический анализ и анализ аналогии, исторический метод, метод гипотез, классификационный и графический метод. После проведенного исследования, используя вышеперечисленных методы, было установлено, что развитие экологического туризма происходило в три этапа, которые повлияли на дальнейшее изучения его сущности. Об этом факте свидетельствует классификация различных типов устойчивого туризма. Это положение дает толчок исследованиям сертификации экотуристских услуг. Кроме того, было установлено, что существует логическая закономерность в программах сертификации экотуризма во всем мире. В результате было выявлено, что практически все процессы сертификации экотуризма успешно функционируют. Кроме того, необходимо заметить, что в настоящее время наблюдается резкое увеличение количество компаний, которые уже прошли сертификацию по предоставлению экотуристских услуг. Стоит сделать акцент на том, что программы, которые проанализированы в этой статье были разделены на несколько этапов (в зависимости от программы сертификации экотуризма), следуя которым компания, желающая пройти выбранный вид сертификации, будет иметь возможность успешно пройти процесс проверки и оценки предоставляемых услуг. К сожалению, в Украине не была выявлена сертификация экотуристских услуг. Стоит заметить, что данная проблема в развитии процесса сертификации экологического туризма является актуальной в настоящее время и требует дальнейших исследований. Практическое значение. Тем не менее, анализ опыта зарубежных стран может стать основой для развития сертификации экотуристских услуг в Украине. Значение/ оригинальность. Моделирование процессов прохождения экотуристской сертификации в разрезе различных международных программ помогло выявить важные аспекты в данном процессе, а также подчеркнуть особенности оценки экотуризма в Украине. 